\title{
Identifying the Classification of EU Countries by an Alternative Variable: The "Stakeholders' Perception"
}

\author{
Marco Sorrentino (Corresponding author) \\ Department of Economic and Legal Sciences \\ Pegaso University, Naples, Italy \\ E-mail: marco.sorrentino@unipegaso.it
}

Benedetta Gesuele

Department of Economic and Legal Sciences, Pegaso University, Naples, Italy

Massimiliano Farina Briamonte

Department of Economics, Parthenope University, Naples, Italy

Fabio Fiano

Department of Economics, Second University of Naples, Capua (CE) - Italy

Received: August 26, 2016 Accepted: October 12, 2016 Published: November 22, 2016

doi:10.5296/ijafr.v6i2.9949 URL: http://dx.doi.org/10.5296/ijafr.v6i2. 9949

\begin{abstract}
Since the first part of 20th century, there was a strand of literature that analyzes international differences in financial accounting practices and uses these differences to classify countries into groups having similar characteristics. For a long time, the two main accounting systems that have been analyzed in these studies were the Anglo-Saxon accounting system and the Continental Europe one. Notwithstanding the last decades have been characterized by a widespread harmonization process through an extensive and often compulsory adoption of IAS/IFRSs, the situation did not changed so much, because there are still a lot of relevant differences in applying IAS/IFRSs. The aim of this research is to contribute to the literature in theme of countries classification using a different type of variable: the "stakeholders' perception" instead of "accounting practices". Using a quantitative statistic methodology, the
\end{abstract}




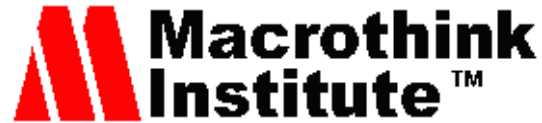

International Journal of Accounting and Financial Reporting

ISSN 2162-3082

cluster analysis, we identify a three-group classification of the EU countries based on the answers about the costs and benefits of IFRS implementation issued in EU public Consultation, launched ten years after their mandatory application.

Keywords: IFRS, costs and benefits, country classification, cluster analysis.

\section{Introduction}

Since the first part of 20th century, there was a strand of literature that analyze international differences in financial accounting practices and use these differences to classify countries into groups having similar characteristics (Lourenço et al., 2015).

For a long time, the two main accounting systems that have been analyzed in these studies were the Anglo-Saxon accounting system and the Continental Europe one (Nobes \& Stadler, 2013). Notwithstanding the last decades have been characterized by a widespread harmonization process through an extensive and often compulsory adoption of IAS/IFRS, the situation did not change so much. Contrary to what one might suppose, many empirical analyses found that there are still a lot of relevant differences in applying IAS/IFRS. It is substantially due both to their principles-based approach that could allow various options and ambiguous interpretations (Ball, 2006; Kvaal \& Nobes, 2010, 2012; Nobes, 2006, 2008, 2011, 2013; Stadler \& Nobes, 2014; Forst \& Salerno, 2016) and to the presence of firms that adopt them more in name ("label firms"), than as a part of a strategy to increase their commitment to transparency ("serious firms") (Daske et al., 2013).

For all these reasons, it is reasonable to assert that trying to classify countries by their accounting systems is still a valuable practice in order to: 1) explain the differences of IAS/IFRS application in different countries; 2) predict the convergence process from domestic standards to IAS/IFRS; 3) identify countries where IAS/IFRS root better (Nobes, 2008).

Starting from these premises, we would like to contribute to the theme of country classification using a different variable to classify the countries: the "stakeholders' perception" instead of "accounting practices".

In August 2014, just after ten years of IAS/IFRS mandatory application, the European Commission launched a public consultation in order to collect the perceptions from different countries stakeholders on the experiences of IFRS implementation.

Within this background, the aim of this research is to identify a classification of the EU countries based on the costs and benefits of IFRS implementation perceived by European stakeholders who responded to the consultation. In particular, the research addresses whether stakeholders from different European countries and who have different legal, bureaucratic and cultures traditions (Fox, Hannah, Helliar, \& Veneziani, 2013) have different views on the IFRS implementation process in terms of costs and benefits perceived. During the research, using a quantitative statistic methodology, the cluster analysis, we make use of a specific set of queries of the EU public consultation questionnaire, in order to highlight the stakeholders' 


\section{Macrothink}

International Journal of Accounting and Financial Reporting

perceptions and identify a European country classification.

Our paper contributes to the literature giving a new evidence in the countries classification studies using a different discriminant variable.

The paper continues as follows. Section 2 describes the literature about accounting classification. Section 3 describes briefly the European Union public consultation, underlining its principal findings, and outlines the methodology of the study. Section 4 presents the relevant results of the study and the research practical findings. Section 5 concludes the paper, describing the implication and future research perspectives.

\section{Classification of Countries by Their Accounting Practices: A Literature Review}

Several scholars propose summary tables, studies and analysis about accounting system classification, with different findings, using different samples and different classification methods (Lourenço et al., 2015). This topic become more and more important considering the great efforts of the international community to create a system shared accounting rules and universally accepted.

The earliest paper on international classification of accounting systems is one hundred years old. In the far 1911, Hatfield studied the accounting systems of four countries: France, Germany, the UK and the USA. His findings show that there are three-group classification where France and Germany are together and UK and USA formed two separated groups. Later, in 1967 Mueller, considering the major accounting backgrounds, found four groups. Differently from Hatfield, he put the USA and the UK in the same group. Other authors generate classifications using data regarding on accounting rules (Seidler, 1967; Mueller, 1968). Otherwise, other scholars (Gray, 1988; Roberts, 1995) used not only the data regarding the accounting rules but also the environmental factors.

In 1980, Nair and Frank made the classification of countries into groups based on their accounting practices, examining in depth the disclosure practices used in the groups identified (table 1).

Table 1. Nair and Frank classification (1980)

\begin{tabular}{|l|l|l|l|}
\hline Group I & Group II & Group III & Group IV \\
\hline Australia & Argentina & Belgium & Canada \\
\hline Bahamas & Bolivia & France & Japan \\
\hline Fiji & Brazil & Germany & Mexico \\
\hline Jamaica & Chile & Italy & Panama \\
\hline Kenya & Colombia & Spain & Philippines \\
\hline
\end{tabular}




\begin{tabular}{|l|l|l|l|}
\hline Netherlands & Ethiopia & Sweden & United States \\
\hline New Zealand & India & Switzerland & \\
\hline Pakistan & Paraguay & Venezuela & \\
\hline $\begin{array}{l}\text { Republic of } \\
\text { Ireland }\end{array}$ & Peru & & \\
\hline Rhodesia & Uruguay & & \\
\hline Singapore & & & \\
\hline South Africa & & & \\
\hline $\begin{array}{l}\text { Trinidad and } \\
\text { Tobago }\end{array}$ & & & \\
\hline United Kingdom & & & \\
\hline
\end{tabular}

In 2008, considering their accounting proxies, Nobes classified the countries into two groups: the CLASS A as strong equity, commercially driven (Cyprus, Denmark, Ireland, Malta, the Netherlands, Normandy, UK) and CLASS B as weak equity, governmental driven, tax dominant (Austria, Belgium, Czech Republic, Estonia, Finland, France, Germany, Greece, Uruguay, Italy, Latvia, Lithuania, Luxembourg, Poland, Portugal, Slovenia, Slovenia, Spain, Sweden).

Three years later, considering only countries that had adopted IAS/IFRS, the same scholar (Nobles, 2011) identified a classification based on their accounting policy (table 2). Despite the common use of international accounting standards, his findings show that remain the two traditional groups: 1) Anglo-Saxon (Australia, UK) and 2) Continental European (Sweden, Germany, France, Italy, Nederland e Spain).

Table 2. Nobes Classification (2011)

\begin{tabular}{|l|l|}
\hline Anglo- Saxon & Continental European \\
\hline Australia & Germany \\
\hline UK & France \\
\hline & Italy \\
\hline
\end{tabular}




\begin{tabular}{|l|l|}
\hline & Holland \\
\hline & Spain \\
\hline
\end{tabular}

Later, also many other empirical analyses found that there are still a lot of relevant differences in applying IAS/IFRS (Nobes \& Stadler, 2013) due both to various options and ambiguous interpretations (Kvaal \& Nobes, 2010, 2012; Nobes, 2006, 2008, 2011, 2013; Stadler \& Nobes, 2014) and to the presence of label serious firms adopters (Daske et al., 2013).

In 2015, Lourenço and colleagues, starting from the IFRS accounting systems classification proposed by Nobes in 2011, analysed the eventually existence of different accounting proxies. The results of this study allow us to identify four groups of countries: (1) Russia; (2) the UK; (3) Nordic countries: Sweden, Denmark, Norway and Finland and (4) other European countries: France, Netherlands, German, Switzerland, Italy, Poland, Belgium and Spain (table 3).

Table 3. Lourenço at other classification (2015)

\begin{tabular}{|c|c|c|c|}
\hline Group 1 & Group 2 & $\begin{array}{l}\text { Group } 3 \\
\text { (Nordic countries) }\end{array}$ & $\begin{array}{l}\text { Group } \quad 4 \quad \text { (Other } \\
\text { European countries) }\end{array}$ \\
\hline \multirow[t]{8}{*}{ Russia } & the UK & Sweden & France \\
\hline & & Denmark & Netherlands \\
\hline & & Norway & German \\
\hline & & Finland & Switzerland \\
\hline & & & Italy \\
\hline & & & Poland \\
\hline & & & Belgium \\
\hline & & & Spain \\
\hline
\end{tabular}

Finally, it is very interesting the study conducted by Forst and Salerno (2016). The authors classify the EU Member States into 3 different groups (Domestic Leaning; IFRS Leaning; IFRS Integrated), considering the similarities in their IFRS implementation choices allowed by the 2002 EU Regulation (table 4). 


\section{Macrothink \\ International Journal of Accounting and Financial Reporting \\ ISSN 2162-3082 \\ 2016, Vol. 6, No. 2}

Table 4. Forst \& Salerno classification (2016)

\begin{tabular}{|l|l|l|}
\hline Domestic Leaning & IFRS Leaning & IFRS Integrated \\
\hline Austria & Czech Republic & Bulgaria \\
\hline Belgium & Denmark & Croatia \\
\hline France & Finland & Cyprus \\
\hline Germany & Ireland & Estonia \\
\hline Hungary & Luxembourg & Greece \\
\hline Poland & Netherlands & Italy \\
\hline Spain & Portugal & Latvia \\
\hline Sweden & Romania & Lithuania \\
\hline & United Kingdom & Malta \\
\hline & & Slovakia \\
\hline
\end{tabular}

\section{Methodology}

In this section, we briefly describe the European Consultation Draft and above all the set of questions used to arrange our statistical analysis. Then we describe the methodology performed during the analysis.

\subsection{The EU Public Consultation on IAS/IFRS Implementation at a Glance}

The EU public consultation on the impact of IAS/IFRS after ten years of their mandatory application was launched by European Commission in August 2014 and was kept open until November of the same year. The consultation received 200 contributions (figure 1). 
Figure 1. Stakeholders who responded to EU public consultation on the impact of IFRS

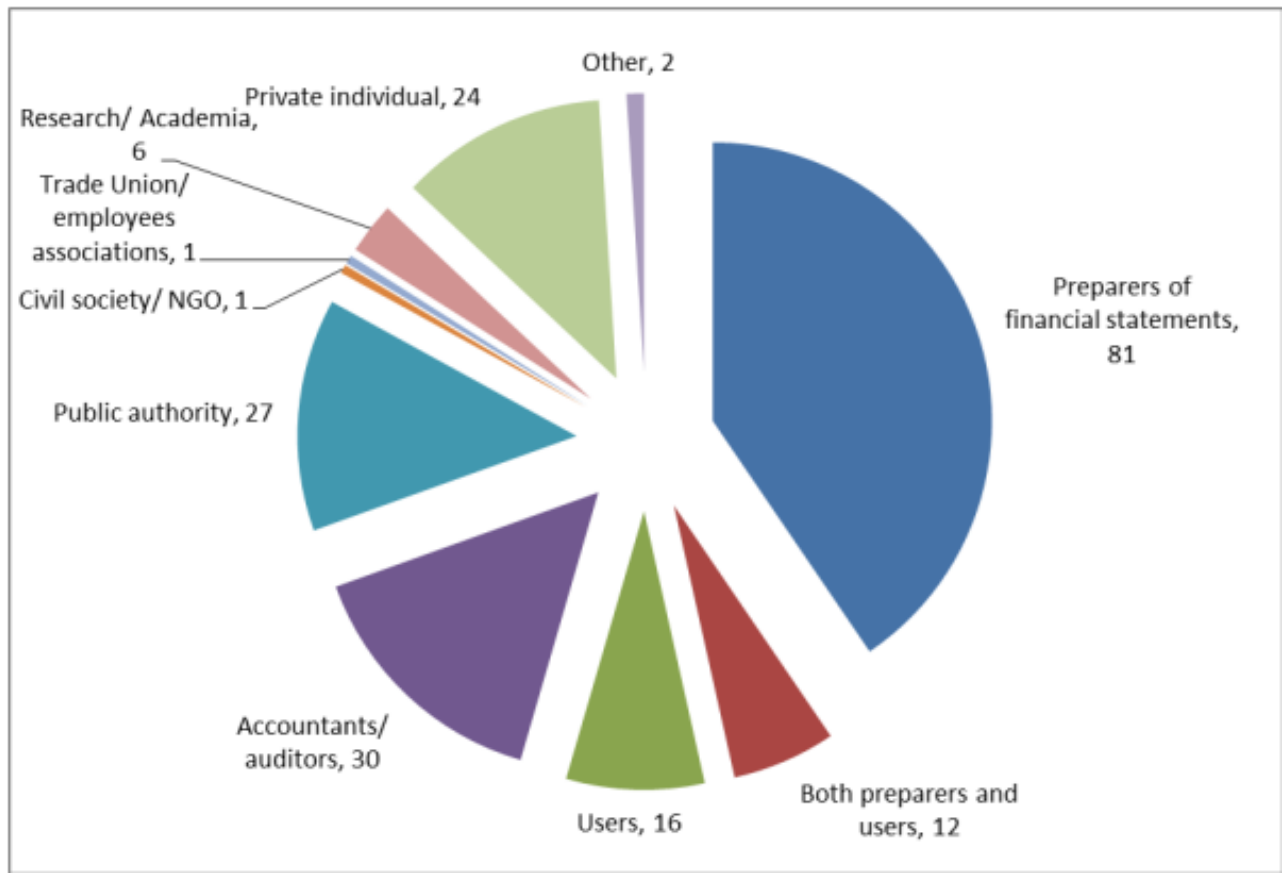

Source: European Commission (2015). Evaluation Of Regulation (Ec) $N^{\circ} 1606 / 2002$ Of 19 July 2002 On The Application Of International Accounting Standard.

The main findings of the consultation are the following (European Commission, 2015, p. 4):

- "The Commission found that the IAS Regulation has increased the transparency of financial statements through improved accounting quality and disclosure and greater value-relevance of reporting, leading to more accurate market expectations including analysts'forecasts. It also led to greater comparability between financial statements within and across industries and countries although some differences persist";

- "The Commission found evidence of improved capital market outcomes: higher liquidity; lower costs of capital; increased cross-border transactions; easier access to capital at EU and global level; improved investor protection and maintenance of investor confidence. However, as noted above, the effects of IFRS could not be isolated from other changes affecting capital markets".

\subsection{The analysis}

The aim of this research is to identify the accounting classification of the EU countries based on the costs and benefits of IFRS implementation perceived by the European stakeholders who responded to the consultation.

In order to answer our research question we made use of a specific set of queries in the European Consultation draft in order to highlight the stakeholders' perceptions. In the following table, we describe the queries chosen (table 5). 


\section{Macrothink \\ International Journal of Accounting and Financial Reporting \\ ISSN 2162-3082 2016, Vol. 6, No. 2}

Table 5. Questions of EU public consultation used for the empirical analysis

\begin{tabular}{|c|c|c|}
\hline $\begin{array}{l}\text { N. of the } \\
\text { question }\end{array}$ & Text of the question & Type of answer \\
\hline 14 & $\begin{array}{l}\text { Has the application of IFRS in the EU } \\
\text { helped create a level playing field for } \\
\text { European companies using IFRS, } \\
\text { compared with the situation before } \\
\text { mandatory adoption? }\end{array}$ & $\begin{array}{l}\text { 1. Yes } \\
\text { 2. No } \\
\text { 3. No Opinion }\end{array}$ \\
\hline 16 & $\begin{array}{l}\text { In your experience, has the application } \\
\text { of IFRS in the EU had a direct effect on } \\
\text { the overall cost of capital for your } \\
\text { company or the companies you are } \\
\text { concerned with? }\end{array}$ & $\begin{array}{l}\text { 1. Cost has fallen significantly } \\
\text { 2. Cost has fallen slightly } \\
\text { 3. No effect } \\
\text { 4. Cost has risen slightly } \\
\text { 5. Cost has risen significantly } \\
\text { 6. No opinion }\end{array}$ \\
\hline 17 & $\begin{array}{l}\text { In your view, has the application of } \\
\text { IFRS in the EU improved protection for } \\
\text { investors (compared with the situation } \\
\text { before mandatory adoption), through } \\
\text { better information and stewardship by } \\
\text { management? }\end{array}$ & $\begin{array}{l}\text { 1. Yes, to a great extent } \\
\text { 2. Yes, to a small extent } \\
\text { 3. It had no impact } \\
\text { 4. No, protection for investors } \\
\text { has worsened } \\
\text { 5. No opinion }\end{array}$ \\
\hline 18 & $\begin{array}{l}\text { In your view, has the application of } \\
\text { IFRS in the EU helped maintain } \\
\text { confidence in financial markets, } \\
\text { compared with the likely situation if it } \\
\text { had not been introduced? }\end{array}$ & $\begin{array}{l}\text { 1. Yes, to a great extent } \\
\text { 2. Yes, to a small extent } \\
\text { 3. It had no impact } \\
\text { 4. No, confidence in financial } \\
\text { markets has decreased } \\
\text { 5. No opinion }\end{array}$ \\
\hline 19 & $\begin{array}{l}\text { Do you see other benefits from applying } \\
\text { IFRS as required under the IAS } \\
\text { Regulation? }\end{array}$ & $\begin{array}{l}\text { 1. Yes } \\
\text { 2. No } \\
\text { 3. No Opinion }\end{array}$ \\
\hline
\end{tabular}




\begin{tabular}{|c|c|c|}
\hline 20 & $\begin{array}{l}\text { In your experience, on balance and at } \\
\text { global level, how do the benefits of } \\
\text { applying IFRS compare to any } \\
\text { additional costs incurred - compared } \\
\text { with the situation before mandatory } \\
\text { adoption, bearing in mind the increasing } \\
\text { complexity of businesses that } \\
\text { accounting needs to portray? }\end{array}$ & $\begin{array}{l}\text { 1. Benefits significantly exceed } \\
\text { the costs } \\
\text { 2. Benefits slightly exceed the } \\
\text { costs } \\
\text { 3. Benefits and costs are } \\
\text { broadly equal } \\
\text { 4. Costs slightly exceed the } \\
\text { benefits } \\
\text { 5. Costs significantly exceed the } \\
\text { benefits } \\
\text { 6. No opinion }\end{array}$ \\
\hline
\end{tabular}

Source: our elaboration

We choose in the Consultation the questions that, in our opinion, better describe the costs and benefits perceived by the respondents. Totally, the voluntary respondents to these specific questions have been 191. They represent the universe for our analysis. From this number, we have eliminated all the answers given by subjects that came from non-UE countries or that replied only to one of the selected questions (statistically not significant). Finally, we selected 110 subjects divided in Civil society organization/non-governmental organization, Auditing firm, Association, Company preparing financial statements, Public authority and Private authority.

The sample is very heterogeneity both as home country (table 6) and as type of stakeholders (table 7).

Table 6. Sample, distribution by home countries

\begin{tabular}{|l|l|}
\hline Country & N. of Respondents \\
\hline Austria & 3 \\
\hline Belgium & 5 \\
\hline Bulgaria & 1 \\
\hline Czech Republic & 4 \\
\hline Denmark & 5 \\
\hline Estonia & 1 \\
\hline
\end{tabular}




\begin{tabular}{|l|l|}
\hline Finland & 1 \\
\hline France & 18 \\
\hline Germany & 27 \\
\hline Greece & 2 \\
\hline Ireland & 1 \\
\hline Italy & 5 \\
\hline Luxembourg & 2 \\
\hline Poland & 2 \\
\hline Spain & 6 \\
\hline Sweden & 3 \\
\hline The Netherlands & 1 \\
\hline United Kingdom & 23 \\
\hline Total & $\mathbf{1 1 0}$ \\
\hline
\end{tabular}

Table 7. Sample, distribution by type of stakeholders

\begin{tabular}{|l|l|}
\hline Type & N. of replays \\
\hline Civil society organization / non-governmental Organization & 10 \\
\hline Auditing firm & 20 \\
\hline Association & 21 \\
\hline Company preparing financial statements & 22 \\
\hline Public authority & 18 \\
\hline
\end{tabular}




\section{Macrothink}

\begin{tabular}{|l|l|}
\hline Private Authority & 19 \\
\hline Total & 110 \\
\hline
\end{tabular}

\subsubsection{The Empirical Analysis}

In the research, we use the cluster analyses, that is somewhat similar to that applied by Nobes (1983, 2011), d'Arcy (2001), Lourenco and colleagues (2015) and Forst and Salerno (2016). In this study, differently from the previous literature and consolidated studies, we choose to analyze not accounting data (Financial Statement data) but qualitative information collected using a set of queries of the questionnaire of EU public consultation. Considering that the data are collected by a survey we expected a presence of strong correlation between them, so we performed the correlation test.

In order to limit the effect of the strong correlation highlighted we performed the categorical factor analysis. Subsequently, we perform a cluster analysis in order to identify the most similar pairs of countries. The cluster analysis performed is the cluster K-MINS. It is able to identify the level of costs and benefits perceived in the sample as statistical value and, as consequence, to express different groups of countries whose stakeholders have similarities in terms of costs and benefits perceived.

Following Dendogram (figure 2) describes the cluster formatted during our empirical evidences. In line with methodology used, we choose to keep out 5 countries that have only up to 1 respondent.

Figure 2. Dendogram of three cluster solution

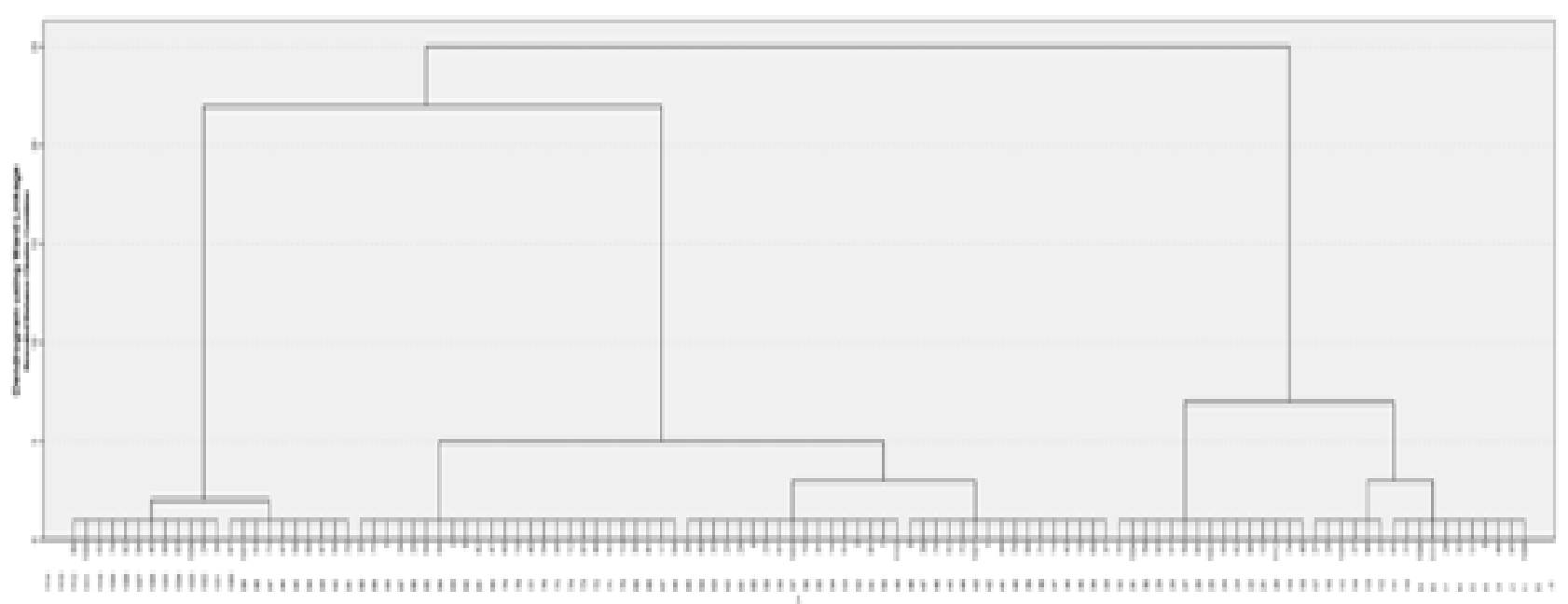




\section{1) Macrothink}

International Journal of Accounting and Financial Reporting

ISSN 2162-3082 2016, Vol. 6, No. 2

\section{Results and Findings}

The results of this analysis allow us to identify three groups of countries: (1) Belgium, Denmark, Germany, Poland, Spain, Sweden and United Kingdom; (2) Austria, Czech Republic, France and Luxembourg; (3) Italy and Greece (table 8).

Table 8. Cluster Analysis

\begin{tabular}{|l|l|l|}
\hline Cluster 1 & Cluster 2 & Cluster 3 \\
\hline Belgium & Austria & Greece \\
\hline Denmark & Czech Republic & Italy \\
\hline Germany & France & \\
\hline Poland & Luxembourg & \\
\hline Spain & & \\
\hline Sweden & & \\
\hline United Kingdom & & \\
\hline
\end{tabular}

The findings of this analysis are quite different from the results of the previous studies based on accounting practices. In this sense, the position of the UK is explanatory. It is placed in the first cluster with Belgium, Denmark, Poland, Sweden and, above all, with typical "continental countries" like Germany and Spain. Indeed, all the previous studies based on accounting practice classified the UK as a single cluster or together with other countries that have Anglo-Saxon accounting tradition (so called, Anglo-Saxon countries). On the contrary, the classification resulting by our analysis is much more similar to Forst and Salerno's one, where countries influenced by Anglo-American accounting practice (namely, United Kingdom and Ireland) are not at the leading of IFRS adoption, but in the same group with different countries such as Czech Republic, Denmark, Luxembourg and even Portugal and Romania.

Analyzing table 4 and table 8 , it is simple to notice that the countries located in the first two groups of our classifications (Cluster 1 and Cluster 2) are overall in the first two groups of Forst and Salerno classification (Domestic Leaning and IFRS Leaning); while Italy and Greece belong to the third group in both classifications (table 9). 


\section{Macrothink \\ International Journal of Accounting and Financial Reporting \\ ISSN 2162-3082 2016, Vol. 6, No. 2}

Table 9. A comparison between Forst \& Salerno and our classification

\begin{tabular}{|c|c|c|}
\hline Country & $\begin{array}{l}\text { Sorrentino \& Gesuele } \\
\text { classification }\end{array}$ & $\begin{array}{l}\text { Forst \& Salerno } \\
\text { classification }\end{array}$ \\
\hline Belgium & Cluster 1 & Domestic Leaning \\
\hline Denmark & Cluster 1 & IFRS Leaning \\
\hline Germany & Cluster 1 & Domestic Leaning \\
\hline Poland & Cluster 1 & Domestic Leaning \\
\hline Spain & Cluster 1 & Domestic Leaning \\
\hline Sweden & Cluster 1 & Domestic Leaning \\
\hline United Kingdom & Cluster 1 & IFRS Leaning \\
\hline Austria & Cluster 2 & Domestic Leaning \\
\hline Czech Republic & Cluster 2 & IFRS Leaning \\
\hline France & Cluster 2 & Domestic Leaning \\
\hline Luxembourg & Cluster 2 & IFRS Leaning \\
\hline Greece & Cluster 3 & IFRS Integrated \\
\hline Italy & Cluster 3 & IFRS Integrated \\
\hline
\end{tabular}

\section{Conclusions, Limits and Future Research Perspectives}

The main statistical technique used in the researches about countries classification is the cluster analysis, which had been used by d'Arcy (2001), by Nobes (1983 and 2011) and more recently by Lourenço and colleagues (2015) and by Forst and Salerno (2016).

The empirical evidence shows that a country classification based on the costs and benefits perception of IAS/IFRS implementation identifies three groups of countries: (1) Belgium, Denmark, Germany, Poland, Spain, Sweden and United Kingdom; (2) Austria, Czech Republic, France and Luxembourg; (3) Greece and Italy.

These results seem to be substantially in contrast with the previous primary country 


\section{MInstitute Macrothink}

International Journal of Accounting and Financial Reporting ISSN 2162-3082

classifications based on their accounting practice, but much more in line with the classification issued by Forst and Salerno (2016). In this sense, it would be possible to conclude that the perceptions of EU stakeholders in terms of (positive and negative) effects produced by IAS/IFRS implementation are coherent with the choices allowed by the 2002 EU Regulation that every EU country made.

The study has several limits as the heterogeneity of the sample. We underline that at the same time this heterogeneity could be considered as a "value added" of the sample characteristics, in fact thanks to this characteristic we have the possibility to know the point of view of different stakeholder types.

Another important limit of the study, in our opinion, is the type of European survey used for the classification that is a voluntary survey and so could be not so representative. We underline this aspect as limit but, at the same time, we emphasize that this aspect is a point in favor for the goodness of the answers, namely people to answer at the Consultation are really interested to the question and, for this reason, they might be very scrupulous to disclosure their opinion.

Our paper contributes to the literature giving an alternative approach to identify the countries classification using a different discriminant variable: the "stakeholders" perception" instead of "accounting practices".

For the future, we propose to repeat the study with a semi-structure interview at a preselected sample in order to limit the heterogeneity of the sample.

\section{References}

Daske, H., Hail, L., Leuz, C., \& Verdi, R. (2013). Adopting a label: Heterogeneity in the economic consequences of IFRS adoptions. Journal of Accounting Research, 51(3), 495-547.

d'Arcy, A. (2001). Accounting classification and the international harmonisation debate - an empirical investigation. Accounting, Organizations and Society, 26(4), 327-349.

Ball, R. (2016). International Financial Reporting Standards (IFRS): pros and cons for investors. Accounting and Business Research, 36(1), 5-27.

European Commission (2015). Evaluation Of Regulation (Ec) No 1606/2002 Of 19 July 2002 On The Application Of International Accounting Standard, http://ec.europa.eu/finance/accounting/docs/ias-evaluation/20150618-report_en.pdf

Forst, A., \& Salerno, D. F. (2016). Ten Years of Mandatory Use of IFRS in the European Union: A Status Report. The Journal of Corporate Accounting \& Finance, 27(5), 29-36.

Fox, A., Hannah, G., Helliar, C., \& Veneziani, M. (2013). The costs and benefits of IFRS implementation in the UK and Italy. Journal of Applied Accounting Research, 14(1), 86-101.

Gray, S. J. (1988). Towards a theory of cultural influence on the development of accounting systems internationally. Abacus, 24(1), 1-15. 


\section{Macrothink}

International Journal of Accounting and Financial Reporting

Hatfield, H. R. (1911). 'Some Variations in Accounting Practices in England, France, Germany and the U.S.', reprinted in Journal of Accounting Research, Autumn 1966, Vol. 4.

Lourenço, I. C., Sarquis, R., Branco, M. C., \& Pais, C. (2015). Extending the Classification of European Countries by their IFRS Practices: A Research Note. Accounting in Europe, 12(2), 223-232.

Kvaal, E., \& Nobes, C. W. (2010). International differences in IFRS policy choice. Accounting and Business Research, 40(2), 173-187.

Kvaal, E., \& Nobes, C. W. (2012). IFRS policy changes and the continuation of national patterns of IFRS practices. European Accounting Review, 21(2), 343-371.

Mueller, G. G., International Accounting, Part I, Macmillan, 1967.

Nair, R. D., \& Frank, W. G. (1980). The impact of disclosure and measurement practices on international accounting classifications. Accounting Review, 55(3), 426-450.

Nobes, C. W. (2006). The survival of international differences under IFRS: Towards a research agenda. Accounting and Business Research, 36(3), 233-245.

Nobes, C. (2008). Accounting classification in the IFRS era. Australian Accounting Review, 18(3), 191-198.

Nobes, C. (2011). IFRS practices and the persistence of accounting system classification. Abacus, 47(3), 267-283.

Nobes, C. W. (2013). The continued survival of international differences under IFRS. Accounting and Business Research, 43(2), 83-111.

Nobes, C. W., \& Stadler, C. (2013). How arbitrary are international accounting classifications? Lessons from centuries of classifying in many disciplines, and experiments with IFRS data. Accounting, Organizations and Society, 38(8), 573-595.

Roberts, A. (1995). The very idea of classification in international accounting. Accounting, Organizations and Society, 20(7), 639-664.

Seidler, L. J. (1967). International accounting--the ultimate theory course. The Accounting Review, 42(4), 775-781.

Stadler, C., \& Nobes, C. W. (2014). The influence of country, industry, and topic factors on IFRS Policy Choice. Abacus, 50, 386-421. 


\section{Macrothink \\ International Journal of Accounting and Financial Reporting \\ ISSN 2162-3082}

\section{Copyright Disclaimer}

Copyright for this article is retained by the author(s), with first publication rights granted to the journal.

This is an open-access article distributed under the terms and conditions of the Creative Commons Attribution license (http://creativecommons.org/licenses/by/3.0/). 